\title{
There is more to education than the demands of the Industrial Revolution 4.0: A focus on literacy expectations
}

\author{
Emerita Professor Heather Fehring \\ School of Education. College of Design and Social Context, \\ RMIT University, Melbourne, Victoria Australia.
}

\begin{abstract}
2020 will bring changing times in education in Australia especially in relation to literacy curriculum policy and procedures. On-going teacher reviews both pre-service and graduate teachers; curriculum reviews especially in relation to the false binary of Synthetic and Analytical phonics and the reconsideration of NAPLAN and PISA following the release of the results of 2018 will be influential in educational policy makers considerations in 2020 . In the current education climate, there is an obsession with the so-called Industrial Revolution 4.0. The driving force for change is dominated by market force perspectives of the future needs for industry workforce skills. The Industrial Revolution 4.0 documented in the current literature commenced in the 18th century with the first Industrial Revolution identified as the invention of the steam engine. In relation to educational change, it is important to reflect on two significant issues. First, there is more to education that the provision of workers skilled to meet industry needs. Only examining industrial workforce needs does not cover the total workplace of society. Secondly, education constantly evolves and adapts to factors affecting student learning. This paper explores some of the key issues related to the place of education within the context labelled as the Industrial Revolution 4.0 in 2020.
\end{abstract}

\section{INTRODUCTION}

The teaching profession has continually undergone Australian Government investigations covering a multitude of areas of political and public interest. As for example, The Top of the Class report (Commonwealth of Australia House of Representatives Standing Committee on Education and Vocational Training (Chair: L. Hartsuyker), February, 2007), Teacher Education Ministerial Advisory Group - TEMAG (Australian Government Department of Education and Training, 2015a, 2015b) the Status of the Teaching Profession report (Parliament of the Commonwealth of Australia House of Representatives Standing Committee on Employment Education and Training, October 2019) and the recent announcement on the on the $15^{\text {th }}$ October 2019, by the Federal Minister for Education, the Honourable Dan Tehan (Minister of Education Honerable Dan Tehan, 15th October 2019) establishing an Australian Institute for Teaching and School Leadership (AITSL) task force to do two things:

- provide AITSL with advice on the inclusion of phonics in national accreditation standards for Initial Teacher Education (ITE); and

- advise on how to ensure graduate teachers can teach the fundamentals of literacy through learning how to teach the five essential elements of literacy: phonemic awareness, phonics, vocabulary development, reading fluency, comprehension.

One of the driving forces in this quest for political educational excellence has been the influence of the notion of the Industrial Revolution 4.0. Current literature defining the parameters of the Industrial Revolution 4.0 identifies four major stages. The Industrial Revolution 1.0 is considered to have begun with the invention of the steam engine, Industrial Revolution 2.0 began with the industry-based production line, Industrial Revolution 3.0 began with the development of the computer and Industrial Revolution 4.0 began in about 2000 with 
the innovation of connectivity (Australian Government Department of Industry and Science, 2019; Intelitek, 2018; Payton, 2017; Seet, Jones, Spoehr, \& Hordacre, 2018; Senate Standing Committee, 2003).

The emphasis on these four stages centres on economic drivers, mainly business, commercial and manufacturing. While not denying the importance of economic drivers from the national and international market perspectives of the 21st century, there is more to the provision of the education of young people entering the workplace and the re-education of employees who need re-skilling. Taking a more holistic view of societal needs in the 21st century means consideration needs to be given to a broad range of diverse influences, as for example: the national and international business, manufacturing and economy; Education, Higher Education Universities, and Vocational Educational and Training.

Thus, the first contention in my argument is that education is more than producing the next generation of skilled workers to meet industry needs. Education needs to meet a multiple of needs for students both young and older. These include:

- social skills of human interaction

- communication skills on a global scale

- negotiation, collaboration and cooperation skills

- innovative and creative thinking

- a culture or philosophy of lifelong learning.

The second contention of my argument is that education constantly evolves and adapts to factors affecting student learning. Rather than the concept of revolution, educators have taken a long-term perspective of adapting to not only the needs of individual learners, but also to the needs of the broader community that encompasses the sectors in Figure 1.

\section{KEYS ISSUES RELATED TO LITERACY EXPECTATIONS, EDUCATION AND CHANGE}

To understand how literacy expectations have evolved, and what that means to education, we need to reflect on the changing nature of literacy. Literacy in 2019 now encompasses many skills and abilities:

- reading

- writing

- listening and speaking

- viewing

- critical and creative thinking

- understanding aural and gestural codes.

All these attributes involve knowledge of the structure of the language we are learning, and the cultural and societal influences affecting the language we learn. Educators need to embrace a philosophical understanding of literacy development that encompasses all learners. I am still of the opinion that Luke and Freebody's literacy model from 1999 - known as the Four Resources Model - is current today and will remain so over the next 20 years (Anstey, 2002; Peter Freebody, 1992, 2004; Peter. Freebody \& Luke, 1992; Henderson, 2019; Luke, 1993; Luke \& Freebody, 1997, 1999). The Four Resources Model has the following features:

- Code breaker. Students need to learn the code of a language. For English, this means the linguistic structures of orthography (graphemes), phonology (sounds), syntax, morphology (word meanings) and etymology (word origins).

- Text participant. Students need to draw on their experiences to interpret and construct a personal meaning to a text. 
- Text analyst. Students need to be able to critically analyse texts to understand how the information is positioning them and what cultural influences impinge on the meaning constructed.

- Text user. Students need to understand how to use the information gained to inform their thinking processes.

Educators need to take on new and challenging demands related to the changing nature of literacy and what this implies for educational practices in 2019 and beyond. Anne Harris is one of the key change agent, both in Australia and internationally, who is driving the concept of creativity as a thinking process that is essential to students who will engage with future workplace demands (Harris, 2016; Harris \& Ammermann, 2016; Harris \& de Bruin, 2017; Lucas, 2017). Anne Harris outlines the top 10 creativity skills and capacities that students require as follows:

- curiosity

- collaboration and teamwork

- problem posing and problem solving

- divergent thinking

- motivation, confidence and persistence

- innovation

- disciplinary mastery

- risk-taking and mistake making

- synthesising

- critical thinking involving analytical thinking.

The Australian Curriculum is an agreed framework by all the ministers of education of the six states and two territories. The Australian Curriculum has encompassed changes by introducing General Capabilities into the structure of the curriculum that supports teachers (see Figure 1; Australian Curriculum and Assesment Authority (ACARA), 2019; Australian Curriculum and Assessment Authority (ACARA), 2018).

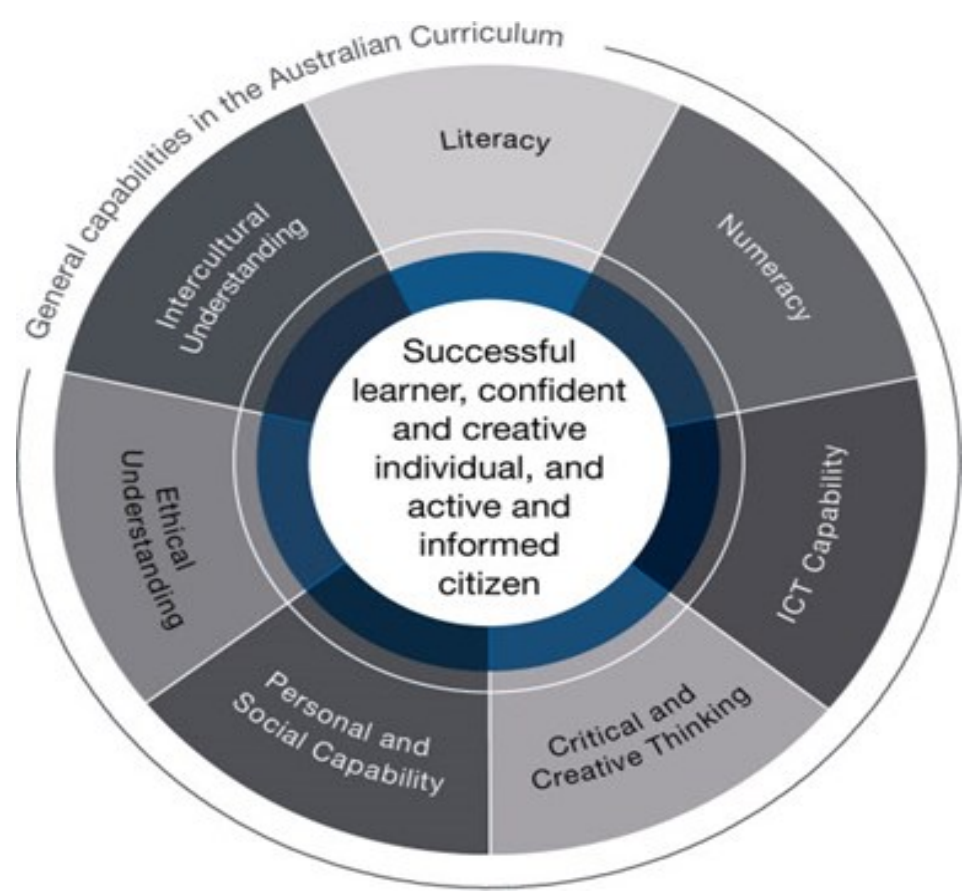

Figure 1: General Capabilities in the Australian Curriculum (Australian Curriculum and Assesment Authority (ACARA), 2019) 
Teaching and learning strategies to develop the complex array of skills and knowledge needed to develop General Capabilities include:

- inquiry-based learning approaches

- interdisciplinary approaches

- teaching thinking skills

- communication

- collaboration

- problem solving and innovation

- teaching practices such as KWL

$\circ$ What do I already know $(\mathrm{K})$ ?

- What do I want to know or learn (W)?

- What have I learned (L)?

- brain storming and building mind maps

- encouraging student to give evidence and reason by asking "why?"

- journal writing

- class arguments or debates

- variety in the types of questioning techniques used in the classroom.

One Victorian school's approach to this change was documented the 2019 ACER Research Conference (ACER, 2019). Loren Clarke and Melissa Hughes from Eltham High School in Victoria have developed an innovative approach to equipping students for active citizenship in the modern world. By combining content knowledge with a focus on the General Capabilities skills of thinking critically, collaborating, communicating and innovating and problem-solving they have changed the learning context of the school curriculum (Clarke \& Hughes, 2019). Using a cross-disciplinary strategy (integrated studies program) with an inquiry model, the teachers have incorporated "big-ideas and real-world learning" (p. 31) opportunities.

Another recent phenomenon in the Industrial Revolution 4.0 period is the concept of disciplinary literacies (Moje, 2007, 2008, 2015). This involves an understanding that mathematicians, scientists, historians and artists understand the world in different ways, and in so doing use language differently to communicate their knowledge. Disciplinary literacies have become the specialised uses of language and thinking processes within a discipline. It is not only vocabulary and texts that are created but also the way that experts think, talk, interact and understand the world. This knowledge has required educators to change their teaching and learning practices to incorporate group work and inquiry learning processes into curriculum content areas and use formative assessment practices (Wiliam, 2011) such as rubrics (author, 2019) to cater for individual learners' progress trajectories.

The evolving nature of what constitutes literacy has provided a driver to change the school curriculum from a linear, lock step and sequential notion of developmental progress that is measured in yearly growth of improvement to a concept of education systems providing personal learning planning for all students. Of course, we are caught in a dilemma when we try to envisage what is required to reform and transform an educational paradigm. First, schooling is based on a philosophy of a linear continuum of sequential development and progress. Schools around the world are based on a compulsory age range principle. In Australia, compulsory schooling is from age five or six years of age to 17 years of age. It is implicitly assumed that a student will grow one year in literacy development with each year of schooling and that each student follows the same path of progress. But this is not the only interpretation of a continuum. Student can follow the same continuum but progress at differential rates. 
Students go to schools that are an architectural structure of buildings housing classes of students. Schools are assumed to be safe places for students to be at from 9 am to 4 pm while their parents are at work. How can this model of education, architecturally driven by efficiency of construction sites, be transformed to a personalised curriculum for every student, as Sir Ken Robinson recommends for the reform of educational systems? Sir Ken Robinson makes the case, as does Andreas Schleicher and the OECD Future of Education and Skills 2030 project, for a radical shift from standardised schools to personalised learning that creates environments where students' talents can flourish (OECD -Centre for Educational Research and Innovation, 2019; Robinson, 2010; Schleicher, 2012). However, the implementation of such a reform has not yet been achieved.

Another educational change that has occurred with the increase in digital literacy required in the 21st century has been the need to address ethical understanding. Students' use of social media platforms and the information that these transmit and receive has come under considerable scrutiny. We now need to educate our students about the ethical understanding of safe, responsible and respectful practices involving social media communication. Literacy educators in the 21st century must combat the impact, not only on students themselves but also on others, of the potentially powerful and destructive influences of social media platforms such as Facebook, YouTube and Twitter. The anonymity and speed of the Internet capabilities have facilitated bullying and scams, which are now a common social consequence of social media innovations. Understanding the power of these literacy practices has changed the way educators take on new educational strategies to combat the negative uses of social media platforms.

\section{WHAT ARE THE IMPLICATIONS FOR EDUCATORS, EDUCATION AND LITERACY IN THE CONTEXT CALLED THE INDUSTRIAL REVOLUTION 4.0?}

First, we need to strengthen teachers' professional literacy judgement through:

- specialist, but flexible, short-duration micro-credentials or modular courses

- using large-scale testing data for diagnostic purposes, not league table production

- enhancing online assessment practices.

These online assessments can be computer scored, constructed for diagnostic information and can produce immediate results for teachers to interpret in relation to their classroom teaching and learning practices. In addition, online testing can be adapted to individualise the curriculum for students. If education systems and teachers develop a common understanding of how students learn through learning progressions (which are common development pathways along which students typically progress in their learning, regardless of age or year level), personalised learning plans can be designed and implemented.

Secondly, in Australia, a skills shortage has re-emerged. This has resulted in the Australian government developing a new apprenticeship policy and program called the Higher Apprenticeship Program (Australian Government 2019).

This Industry 4.0 Higher Apprenticeship Program trains technicians to a high skill level to meet the needs of the economy of the future. The Australian government funds the apprenticeship program through the Skilling Australians Fund and it is led by the Australian Industry Group. The Higher Apprenticeship Program model is similar to a traditional paid apprenticeship. Apprentices may also enrol in an Associate Degree that covers topics including:

- advanced manufacturing processes

- automation and robotics

- Internet of Things (IoT) 
- cloud computing

- advanced algorithms

- smart sensors.

Some universities are investigating micro-credentialing programs to accommodate a shift in thinking about adaptive futuristic education offerings. In response to growing evidence that "the formal qualification system is unlikely to cope, burdened with ever-increasing cost" (Oliver, 2019, p. i) and an increasing realisation that "by 2030, up to 14 percent of the global workforce will need to switch occupational categories. ..." (Oliver, 2019 p. 1), microcredentialing is seen as a viable alternative to traditional degree-structured education. Such Micro-credentialing programs provide a blend of industry education needs and high-level thinking skills programs. One such innovation is the launch of a new centre at the University of Melbourne called MSPACE (Melbourne School of Professional and Continuing Education). MSPACE has begun to develop micro-credentialing programs that will commence in 2020. The idea is to connect industry and education to develop short programs to develop high-level skills. "MSPACE provides lifelong learning opportunities via exceptional, professional, continuing and executive education programs. ... We deliver a range of flexible online, face-toface and blended study options to redefine best practice in professional, continuing and executive education Melbourne University (2019).

Beverley Oliver (2019), in her paper entitled "Making micro-credentials work for learners, employers and providers", makes the following point: "In the digital economy where ongoing upskilling is required for the future of work, micro-credentials and other forms of non-formal learning are rapidly emerging and making the landscape even more complex for learners, employers and providers" (DTeach, Deakin University, 2019 , p. 1)

The skills shortage has also been associated with a decline in students taking science, technology, engineering and mathematics (STEM) subjects and courses (Australia Government Office of the Chief Scientist, September, 2014; Department of Education and Training Victoria, 2016, September). To combat the STEM decline, education authorities have created an innovative solution. In Victoria, Australia, the Department of Education and Training has funded the creation of science and mathematics specialist centres (Department of Education and Training Victoria, 2019). Currently, there is a network of six Victorian science and mathematics specialist centres that engage students and teachers across the state in contemporary and authentic science, technology, engineering and mathematics learning experiences. The centres' programs are available to all Victorian students and their teachers. Programs can be delivered through an on-site visit to the centres or through participation in a virtual program or through having centre staff visit schools as part of the centres' outreach programs.

The centres are for all Victorian students from Foundation to Year 12, with priority given to rural, regional and disadvantaged schools. The centres work in partnership with industry and universities, and collectively have provided inspiration to over 77,000 school students and their teachers (Department of Education and Traing Victoria, 2019). This initiative is optimistically expected to increase the number of students engaged with STEM courses, which in turn will increase students' ability to choose STEM-related careers. It needs to be recognised that this is a long-term strategy.

\section{CONCLUSION}

As literacy evolves and changes, educators will continue to address new challenges and create dynamic teaching and learning environments that respond to the variety of demands in 
different societies. The challenge is not to address new issues from a narrow sector perspectives points of view, but to use holistic student-centred perspectives that cater for the many needs of a society.

- It is important to remember that literacy, as it evolves to cater for the needs of all sectors of the society, will remain a fundamental human attribute.

- Higher Education and Vocational Education and Training have been too slow to adapt to the changing needs of education for the next 10-20 years. This is not surprising because they are huge bureaucracies, often with conflicting internal objectives. However, these institutions need to reassess their priorities and refocus their thinking. Higher Education and Vocational Education and Training institutions need to not only integrate market and industry forces, but also to emphasise the importance of high-level thinking skills catering for learners of the future workplace.

- Schooling needs to maintain a balanced approach to the provision of education for the future. Educators need to maximise the efficiency of digital technology advances, incorporate the development of high-level thinking skills and move from the linear, lock step and sequential concept of developmental progress.

- Educators must always remember that there is more to education than just responding to market labour workforce demands.

\section{References}

ACER. (2019). Research Conference 2019. Preparing students for life in the 21st century: Identifying, developing and assessing what matters. 4-5 August 2019, Melbourne Convention and Exhibition Centre. Retrieved from https://pivotal.acer.edu.au/files/Research-Conference-2019-Proceedings-and-Program.pdf

Anstey, M. (2002). The four resources model. Literate futures: Reading (pp. 27-48). Coorparoo DC, Queensland: Curriculum Innovation Branch, Curriculum Directorate, Department of Education Queensland.

Australian Government Department of Education and Training. (2015a). Australian Government Response to the Teacher Education Ministerial Advisory Group (TEMAG) Report. Action Now: Classroom Ready Teachers. Retrieved from https://docs.education.gov.au/node/36789

Australian Government Department of Education and Training. (2015b). Students First. Retrieved from http://www.studentsfirst.gov.au

Australia Government Office of the Chief Scientist. (September, 2014). Science, Technology, Engineering and Mathematics: Australia's Future. Retrieved from http://www.chiefscientist.gov.au/wpcontent/uploads/STEM AustraliasFuture Sett2014 Web.pdf

Australna Government (2019). Higher Apprenticeship Program. https://www.industry.gov.au/funding-andincentives/manufacturing/industry-40 Access 5.8.2019.

Australian Curriculum and Assesment Authority (ACARA). (2019). Australian Curriculum: General Capabilities Retrieved from ttps://www.australiancurriculum.edu.au/f-10-curriculum/general-capabilities/

Australian Curriculum and Assessment Authority. (2018). Australian Curriculum. Retrieved from https://www.australiancurriculum.edu.au/

Australian Government Department of Industry and Science. (2019). Industry 4.0. Australian Government Retrieved from https://www.industry.gov.au/funding-and-incentives/manufacturing/industry-40.

Clarke, L., \& Hughes, M. (2019). Teaching and assessing the general capabilities in a secondary school context. Paper presented at the ACER Research Confercne 2019. Preparing students for life in the 21st century: Identifying, develping and assessing what matters., Melbourne Convention and Exhibition Centre, 4-5 August 2019. https://pivotal.acer.edu.au/files/Research-Conference-2019-Proceedings-and-Program.pdf

Commonwealth of Australia House of Representatives Standing Committee on Education and Vocational Training (Chair: L. Hartsuyker). (February, 2007). Top of the class. Report of the inquiry into teacher education. Retrieved from Canberra, ACT: http_www.aphref.aph.gov.au_house_committee_ert_teachereducation_report_fullreport.pdf

Department of Education and Training Victoria. (2019). Science and Mathematics Specialist Centres. Retrieved from https://www.education.vic.gov.au/about/programs/learningdev/vicstem/Pages/centres.aspx 
Department of Education and Training Victoria. (2016, September). VicSTEM: STEM in the Education State. Retrieved from

http://www.education.vic.gov.au/Documents/about/programs/learningdev/vicstem/STEM EducationState Plan .pdf

DTeach, Deakin University, (2019). Web release of report by Beverley Oliver.

http://dteach.deakin.edu.au/2019/08/02/microcredentials/

AUTHOR (2019)

Freebody, P. (1992). A socio-cultural approach: Resourcing four roles as a literacy learner. In A. J. Watson \& A. M. Badenhop (Eds.), Prevention of reading failure (pp. 48-60). Gosford, NSW: Scholastic Australia Pty Ltd.

Freebody, P. (2004). Hindsight and foresight: Putting the four roles model of reading to work in the daily business of teaching. In A. Healy \& E. Honan (Eds.), Text next: New resources for literacy learning (pp. 3-17). Sydney: PETAA.

Freebody, P., \& Luke, A. (1992). A socio-cultural approach: Resourcing four roles of a literacy learner. In A. Watson \& A. Badenhop (Eds.), Prevention of reading failure. Sydney, Australia \& Auckland, New Zealand: Ashton Scholastic.

Harris, A. (2016). Creativity and education. London, UK: Palgrave, Macmillan/Springer.

Harris, A., \& Ammermann, M. (2016). The changing face of creativity in Australian education. Teaching Education, 27(1), 103-113. doi:http://doi/10.1080/10476210.2015.1077379

Harris, A., \& de Bruin, L. (2017). STEAM education: Fostering creativity in and beyond secondary school. Australian Art Education, 38(1), 54-75.

Henderson, R. (Ed.) (2019). Teaching literacies. Pedagogies and diveresity (2nd ed.). Melbourne, Victoria: Oxford University Press.

Intelitek. (2018). The Education 4.0 Revolution. An analysis of Industry 4.0 and its effects on education. Retrieved from https://www.intelitek.com/ and http://go.pardot.com/l/141221/2018-05-08/35723t

Lucas, B. (2017). Teaching creative thinking. Developing learners who generate ideas and can think critically. Melbourne, Australia: Corwin.

Luke, A. (1993). The social construction of literacy in the primary school. In L. Unsworth (Ed.), Literacy learning and teaching: Language as social practice in the primary school (pp. 1 - 53). South Melbourne, Australia: Macmillan.

Luke, A., \& Freebody, P. (1997). Shaping the social practices of reading. In S. Muspratt, A. Luke, \& P. Freebody (Eds.), Constructing critical literacies: Teaching and learning textual practice (pp. 185-225). St Leonards, NSW: Allen \& Unwin.

Luke, A., \& Freebody, P. (1999). Further notes on the four resources model. Retrieved from http://www.readingonline.org/research/lukefreebody.html No longer avaialable for this online site.

Melbourne University (2019). MSPACE. https://mspace.unimelb.edu.au/

Minister of Education Honerable Dan Tehan. (15th October 2019). Media release: Bringing Phonics into Australia Schools. Retrieved from https://ministers.education.gov.au/tehan/bringing-phonics-australian-schools.

Moje, E., Birr. (2007). Developing socially just subject-matter instruction: A review of the literature on disciplinary literacy teaching. Review of Research in Education, 31(March), 1-44.

Moje, E., Birr. (2008). Foregrounding the disciplines in secondary literacy teaching and learning: A call for change. Journal of Adolescent \& Adult Literacy, 52(2, October), 96-107.

Moje, E., Birr. (2015). Doing and teaching disciplinary literacies with adolescent learners: A social and cultural enterprise. Harvard Educational Review, 85(2), 254-301.

OECD Centre for Educational Research and Innovation. (2019). Trends shaping education. http://doi.org/10.1787/trends_education-2019-en Paris, France: OECD.

Oliver, B. (2019). Making Micro-Credentials Work for Learners, Employers and Providers. Retrieved from http://dteach.deakin.edu.au/2019/08/02/microcredentials/ Full Report http://dteach.deakin.edu.au/wpcontent/uploads/sites/103/2019/08/Making-micro-credentials-work-Oliver-Deakin-2019-exec-summary.pdf Executive Summary

Payton, A. (2017). Skilling for tomorrow. Paper presented at the 26th National VET Research Conference 'No Frills' Hobart, Tasmania. https://www.ncver.edu.au/research-and-statistics/publications/all-publications/skilling-fortomorrow 
Parliament of the Commonwealth of Australia House of Representatives Standing Committee on Employment Education and Training. (October 2019). Status of the Teaching Profession. Retrieved from

https://parlinfo.aph.gov.au/parlInfo/download/committees/reportrep/024385/toc_pdf/Statusoftheteachingprof ession.pdf;fileType=application $\% 2 \mathrm{Fpdf}$

Robinson, K. (2010). TED2010 Bring on the learning revolution! Retrieved from https://www.ted.com/talks/sir ken robinson bring_on the revolution?language=en

Schleicher, A. (2012). TEDGlobal 2012. Use data to build better schools. Retrieved from https://www.ted.com/talks/andreas_schleicher_use_data_to_build_better_schools?language=en

Seet, P.-S., Jones, J., Spoehr, J., \& Hordacre, A.-L. (2018). The Fourth Industrial Revolution: The implications of technolgy disruption for Australian VET. Retrieved from Adelaide, SA https://www.ncver.edu.au/research-andstatistics/publications/all-publications/the-fourth-industrial-revolution-the-implications-of-technologicaldisruption-for-australian-vet

Senate Standing Committee. (2003). Bridging the skills divide. Canberra, Australia: Commonwealth Government of Australia.

Wiliam, D. (2011). Embedded formative assessment. Bloomington, IN: Solution Tree Press.

\section{Emerita Professor Heather Fehring}

\section{ABOUT THE AUTHOR}

Emerita Professor Heather Fehring has held many academic and leadership positions throughout her career. She has taught and published across the spectrum of educational sectors. Her passion for excellence in teaching has been acknowledged by the ten teaching awards. Her commitment to research has resulted in a number of funded projects. As an Emerita Professor in 2020 Heather continues to supervise PhD candidates, mentor staff for promotion and deliver professional development sessions to international delegations. 